\title{
N-Terminal ProA-type Natriuretic Peptide Measurement
}

National Cancer Institute

\section{Source}

National Cancer Institute. N-Terminal ProA-type Natriuretic Peptide Measurement. NCI Thesaurus. Code C139088.

The determination of the amount of $\mathrm{N}$-terminal proA-type natriuretic peptide present in a sample. 